\title{
Hybrid Organizations as Shape-Shifters: Altering Legal Structure for Strategic Gain
}

\author{
Nardia Haigh \\ Elena Dowin Kennedy \\ John Walker
}

Social entrepreneurs navigate a complex landscape of legal structures in which they need to select among forprofit, nonprofit, and mixed-entity structures. This study of 48 hybrid organizations identifies why social entrepreneurs chose one legal structure over another and explains what motivates half of them to change their legal structure as they build their enterprise. It highlights the critical desire for flexibility among social entrepreneurs, discusses the implications that changes to legal structure may have for companies and hybrids in partnerships, and explores how companies can leverage hybrid structures to go beyond their current scope of CSR initiatives. (Keywords: Hybrid Organizations, Social Enterprise, Business Models)

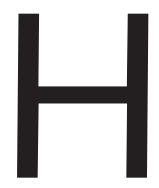

ybrid organizations are unique in their need and ability to traverse nonprofit/for-profit legal structures. Runa, a hybrid organization that produces Guayasa beverages and supports Ecuadorian farmers, has gone through several changes to its legal structure since its founding in 2008. Guayasa trees grow in the Ecuadorian Amazon, and for generations Ecuadorians have made a drink from its caffeinated leaves. After visiting Ecuador and witnessing ineffective development projects and deforestation, CEO Dan Macombie and his business partner Tyler Gage designed Runa as a for-profit company with a mission of supporting Guayasa farming communities by purchasing Fair Trade Guayasa to produce beverage products. According to Macombie, soon after establishing the for-profit they added a nonprofit to ensure their suppliers understood Runa's social mission: “Originally, the supply chain in Ecuador was under the nonprofit because we believed that that was necessary for communicating our social mission to farmers." However, after realizing the farmers did not mind whether they traded with a for-profit or nonprofit and that managing

The authors thank David Vogel and our three anonymous reviewers for their helpful comments and suggestions. Further, we are grateful for funding from the University of Massachusetts Boston Joseph P. Healey Research Grant, which made the study possible. 
Nardia Haigh is an Assistant Professor of Management in the College of Management at the University of Massachusetts Boston.

Elena Dowin Kennedy is a Ph.D. Candidate in the College of Management at the University of Massachusetts Boston, specializing in Organizations and Social Change.

John Walker is the Director of Finance and Business Development at A-List Education and an Adjunct Associate Professor at Columbia Business School. suppliers through a nonprofit "was not a very effective way of doing business," Macombie and Gage transitioned their suppliers to the for-profit. Today, the for-profit "focuses on building a supply chain for Guayasa," while the nonprofit "focuses on socio-economic research and program development, reforestation... and agricultural ecological research... in conjunction with the farmers." The types of changes to legal structure experienced by Runa are common, and among the 48 hybrid organizations we studied, 24 had made comparable changes or were anticipating them imminently.

We use the term hybrid organization (or hybrid) to refer to enterprises that mix aspects of for-profit and nonprofit realms ${ }^{1}$ to solve specific social or environmental issues while striving to remain economically sustainable. ${ }^{2}$ On a continuum ranging from pure traditional for-profit companies at one end to pure nonprofit charities at the other, hybrids occupy the intermediate points in between. ${ }^{3}$ Hybrids are also labeled social enterprises, ${ }^{4}$ and we use the terms interchangeably. Similarly, entrepreneurs building hybrid organizations are called hybrid entrepreneurs ${ }^{5}$ or social entrepreneurs, which Bacq and Janssen ${ }^{6}$ define as entrepreneurs whose objective is to create social value from entrepreneurial behavior.

Stemming from their dual focus on social and economic goals, social entrepreneurs have three broad options for their legal structure: a for-profit structure that integrates a strong social mission; ${ }^{7}$ a nonprofit structure that earns some or all of its revenue; and what we call a "mixed-entity" structure that associates a for-profit with a nonprofit through ownership, contracts, donations, or other means. Sidebar 1 provides examples from our dataset of each type of hybrid structure.

\section{Sidebar I. Examples of Each Type of Hybrid Structure}

For-Profit Hybrid-Nerd Fitness is a U.S.-based company founded by Steve Kamb. He was a keen online gamer who understood the social dynamics in the gaming community, and the pressures to keep playing rather than getting out and exercising. He was also a fitness advocate who had come to believe that the online fitness industry needed an overhaul. As Kamb put it, "anywhere you turn online, it's people promoting drinks and specific pieces of workout equipment...there's a lot of really bad information out there." In response, he developed a health regime to which gamers could relate and built an online community around it. To ensure he was not contributing to the issues he saw in the online fitness industry, Kamb decided not to advertise or to let others advertise on the Nerd Fitness website, and he continues to build the business through word-of-mouth. He saw an opportunity that would provide him 
with business income while building a community of "people that are interested in staying nerdy but also need help with trying to get healthy."

Nonprofit Hybrid-Project Have Hope exemplifies one case in a wellestablished trend of nonprofits earning revenue to supplement or replace other revenue streams. To some this trend is questionable, ${ }^{\mathrm{a}}$ while others see it as a necessary response to an insecure funding environment. ${ }^{\mathrm{b}}$ Project Have Hope operates under the U.S. IRS's nonprofit 50 I (c)(3) category and seeks to help the Acholi women of Uganda build their own enterprises and educate their children by facilitating the online sale of jewelry and other products they make. Rather than seeking donations to fund its operations, founder Karen Sparacio decided that Project Have Hope would earn its own revenue through buying or consigning the hand-made products and listing them for sale on its website. Proceeds of the sales go to the women, provide working capital for Project Have Hope, and fund programs and partnerships in Uganda. One such partnership is with Uganda Child Cancer Foundation, which is funded through a "Hope Cures" jewelry collection. Project Have Hope's website mentioned that: "One dollar from each Hope Cures bracelet purchased is donated to UCCF to provide emotional, financial and social support, and mobilize resources to improve the children's quality of life."

Mixed-Entity Hybrid-Souktel is a Ramallah-based mixed-entity hybrid that has developed a text-based (SMS-based) job information platform that enables job seekers to connect with organizations looking to hire in regions where access to internet and smartphones is limited. Organizations that are seeking to hire pay Souktel to post an ad, which it distributes to job seekers via text, and interested job seekers respond via text. Souktel began as a U.S.-registered for-profit corporation, but an opportunity arose to develop software that assists the distribution of humanitarian aid. The organization added a Canadian-registered nonprofit entity so that, in the words of cofounder Jake Korenblum, "we could more effectively deliver services or implement technology for exclusively humanitarian purposes in settings where a for-profit model didn't really make sense." Souktel's website now reflects the expanded mission of designing and delivering "custom mobile solutions that connect job seekers with employers, and help development implementers get information to and from the people they serve." The for-profit manages the mobile platform and works with clients, while the nonprofit partners with humanitarian aid organizations, develops software to assist their activities and distributes it at below market cost. Since its founding in 2006, Souktel has reached over half a million mobile phone users in 12 countries and has raised over $\$ 1$ million in venture capital funding.

a. A.M. Eikenberry and K. Jodie Drapal, "The Marketization of the Nonprofit Sector: Civil Society at Risk?" Public Administration Review, 64/2 (March 2004): I32-140.

b. J. Kickul and T.S. Lyons, Understanding Social Entrepreneurship: The Relentless Pursuit of Mission in an Ever Changing World (New York, NY: Routledge, 2012); L. Moeller and V. Valentinov, "The Commercialization of the Nonprofit Sector: A General Systems Theory Perspective," Systemic Practice and Action Research, 25/4 (August 2012): 365-370. 
Having three broad options from which to choose and deciding which is best for a hybrid organization can be complex enough, but there is also growing complexity among for-profit options. In addition to traditional for-profit registration categories (such as LLC and C-Corporation in the U.S.), in some regions hybrids may also register as one of several new for-profit categories serving enterprises with dual social-economic missions. Sidebar 2 describes these categories.

\section{Sidebar 2. New Business Registration Categories for Social Enterprises}

In an increasing number of U.S. States and in the UK, new for-profit categories are available to enterprises emphasizing a dual social_economic purpose. These categories were created in response to requests from social entrepreneurs and their allies to help meet the unique needs of hybrid organizations. These categories are variations of existing for-profits, and depending on the circumstances may not only suit for-profit hybrids, but also those that would traditionally register as nonprofit. In the U.S., these structures differ by state and include variations of the Limited Liability Company (LLC) (e.g., Low-Profit Limited Liability Company (L3C) and Benefit LLC), and variations of the corporation (e.g., Benefit Corporation and Flexible Purpose Corporation). At the time of writing, 27 U.S. states had enacted such legislation and it had been proposed in a further 14. These new categories are part of a dynamic landscape -in January 2014, North Carolina abolished its L3C category (after introducing it in 2010) on the grounds of it not being necessary. ${ }^{\mathrm{b}}$ Across the Atlantic, the UK introduced the Community Interest Company (CIC) in 2005 — a designation that LLCs with primarily social objectives can request. CIC profits are reinvested into its operations rather than being distributed to owners. To date, over $4000 \mathrm{ClCs}$ have been registered. ${ }^{c}$

\footnotetext{
a. B-Lab, <http://bcorporation.net/>, accessed November 4, 2014.

b. A. Field, "North Carolina Officially Abolishes The L3C," Forbes, January II, 2014.

c. "Regulator of Community Interest Companies," Annual Report 2012/2013, <https://www.gov.uk/ government/uploads/system/uploads/attachment_data/file/243869// 3-p | 17-community-interestcompanies-annual-report-2012-2013.pdf>, accessed December 28, 2013.
}

The complex landscape in which social entrepreneurs design hybrid organizations prompted us to ask 'What drives the founders of hybrid organizations when choosing their initial legal structure?' Our study identified 13 drivers that involve a mixture of personal and strategic motives for choosing a for-profit, nonprofit, or mixed-entity structure. After learning of changes to structure among the first three hybrids we initially studied, we added a further research question: Why do hybrid organizations change their legal structure? Half of the 48 hybrids we studied had or were about to alter their legal structure, with many shifting to become mixed-entity hybrids. 
The legal structure ultimately chosen by social entrepreneurs has implications for both the enterprise and its stakeholders. Beyond basic for-profit and nonprofit constraints-such as the inability of nonprofits to distribute earnings for private benefit, while for-profits generally do not access grant or philanthropic funding ${ }^{8}$ - a hybrid's structure influences its partnership opportunities. There are a growing number of social partnerships and social alliances between nonprofits or hybrids and traditional firms to carry out corporate social responsibility (CSR) and corporate sustainability initiatives. ${ }^{9}$ Companies collaborate with hybrids because they see value in their partner's contribution and expect some kind of benefit themselves. ${ }^{10}$ Partnerships are built based on their likelihood of producing collective strength and legitimacy, the degree of interdependence, and low potential for conflict. ${ }^{11}$ The legal structure adopted affects which types of partners (e.g., government agencies, companies, and NGOs) might be willing to work with the enterprise to resolve a focal social issue, and changes to that structure may have implications for an existing partnership.

One organization that articulates the possibility of altering its value proposition to partners is MTI Integrated Business Development, Inc. (MTI IBD). MTI IBD is a 501 (c)(3) nonprofit based in New Jersey that helps injured veterans overcome employment and community integration barriers through its work restoration program Jobs2Vets. MTI IBD trains veterans through its catering, greenhouse, driving range, and other revenue-generating operations, and its website reports that it "is a consultant to the Veteran Affairs New Jersey Health Care System's (VANJHCS) Department of Homeless Services." When we interviewed CEO Wendell Knight, he was working on placing the revenue-generating activities within a for-profit subsidiary of the nonprofit, but was thinking deeply about its potential effect on MTI IBD's existing relations with Veteran Affairs:

"People tend to be less suspicious of you when you are doing these types of revenue generating interests as a not-for-profit, as when you are doing it as a for-profit they tend to be much more suspicious of you. So it's a vetting process for people getting to know who you are and getting to trust you and I find it to be very difficult."

Our results provide insights into what drives social entrepreneurs to choose and then change their legal structure, and indicate how such changes can alter the value that firms get from partnerships with hybrids. In addition to this, our results carry insights for companies wanting to deepen their own CSR commitment beyond partnerships. The hybrid organizations we examined were designed to address social issues, and traditional firms wanting to advance their CSR program could leverage hybrid structures to do so.

\section{Methodology}

The complexity of the legal structure landscape and lack of in-depth research in the area indicated that qualitative methods were appropriate for this study. ${ }^{12}$ We developed 48 case studies of hybrid organizations. Hybrids were recruited through global snowball sampling ${ }^{13}$ of self-identified social entrepreneurs who had founded or managed a hybrid organization. In a field that has 
no central registry or large database of participants, this sampling technique helped us identify a range of hybrid organizations and allowed for a natural depiction of the field. ${ }^{14}$ We first recruited social entrepreneurs known to us, and then others using LinkedIn and Twitter. In each interview, we asked participants to refer us to other hybrid organizations. Table 1 provides a breakdown of the cases in terms of types of organization, the issues on which they focused, and countries in which they were operating.

The cases consist of transcripts or field notes from interviews with founders or senior managers, follow-up e-mails, archival documents, and website content (data collected are summarized in Table 2). We conducted at least one interview for each case, by either phone or Skype, and recorded them when permitted. We performed content analysis of all data using NVIVO qualitative analysis software and used pattern-matching techniques ${ }^{15}$ to identify and interpret emergent drivers. Our initial coding identified 38 drivers of initial choice and changes to legal structures. Further pattern-matching analysis and discussion among the researchers facilitated by spreadsheets reduced the number of drivers and attributed drivers to one or both decision points. The final list in Table 2 contains 13 drivers of initial choice and 11 drivers of structural change, which we report further below in the results.

TAB LE I. Summary of Case Studies

\begin{tabular}{|c|c|c|c|}
\hline $\begin{array}{l}\text { Current Legal } \\
\text { Structure }\end{array}$ & $\begin{array}{l}\text { Number of } \\
\text { Cases }\end{array}$ & Broad Focal Issues & Headquarters \\
\hline $\begin{array}{l}\text { For-Profit } \\
\text { (including } 6 \\
\text { registered as } \\
\text { L3C, Benefit } \\
\text { Corporation, or } \\
\text { similar) }\end{array}$ & 22 & $\begin{array}{l}\text { Employment for the poor, promotion of } \\
\text { sustainable lifestyles, providing } \\
\text { telecommunications in low-income areas, } \\
\text { childhood nutrition, food security, animal } \\
\text { welfare, community revitalization and } \\
\text { localization, obesity, development of } \\
\text { medical devices for developing countries, } \\
\text { and support for sustainable small businesses, } \\
\text { nonprofits, and local artisans }\end{array}$ & $\begin{array}{l}\text { USA, Mexico, } \\
\text { Nicaragua, Mali, UK, } \\
\text { Kenya, and Canada }\end{array}$ \\
\hline Nonprofit & 14 & $\begin{array}{l}\text { Employment (for veterans, youth, refugees, } \\
\text { people with disabilities, mental health or } \\
\text { substance abuse issues, and dependents of } \\
\text { soldiers), charter school management, } \\
\text { support for cancer patients, preventing } \\
\text { migration of local entrepreneurs, providing } \\
\text { materials for under-resourced teachers, } \\
\text { support for Ugandan craftswomen, and } \\
\text { transport for low-income families }\end{array}$ & $\begin{array}{l}\text { Australia, UK, USA, } \\
\text { South Africa, } \\
\text { Canada, and Ireland }\end{array}$ \\
\hline $\begin{array}{l}\text { Mixed-Entity } \\
\text { Hybrid }\end{array}$ & | | & $\begin{array}{l}\text { Infant mortality, employment (for veterans, } \\
\text { the poor), support for women in business, } \\
\text { support for local artisans, support for } \\
\text { indigenous farmers, support for Amazonian } \\
\text { communities, etiquette and financial training } \\
\text { for low-income families, and sanitation in } \\
\text { developing countries }\end{array}$ & $\begin{array}{l}\text { USA, Kenya, } \\
\text { Palestine, UK, and } \\
\text { South Africa }\end{array}$ \\
\hline $\begin{array}{l}\text { Undecided* } \\
\text { Total }\end{array}$ & $\begin{array}{r}1 \\
48\end{array}$ & Support for local performance artists & USA \\
\hline
\end{tabular}

* Although this participant had not yet established their enterprise (and so we were not able to collect data about the type of legal structure ultimately chosen), they did provide useful data regarding what was driving their decision. 
TABLE 2. Data Collected

\begin{tabular}{lc}
\hline Source & Number \\
\hline Interviewees & 43 \\
$\quad$ Founders & 6 \\
Senior managers with substantial detailed knowledge of decision making at founding & 1 \\
Senior manager with good working knowledge of decision making at founding & $\mathbf{5 0}$ \\
Total Number of Founders/Managers Interviewed & \\
Documents & 9 \\
$\quad$ Follow-up e-mails with interviewees & 10 \\
Brochures, press releases, business plans, and other documents & $\mathbf{1 9}$ \\
Total Number of Documents & $\mathbf{4 7}$ \\
Websites &
\end{tabular}

Interviews and follow-up e-mails were valuable for identifying primary, secondary, and tertiary reasons for choosing the initial legal structure of each hybrid, and where applicable the reasons for changes made to that structure. In most cases, multiple drivers influenced choices of initial structure and changes. Through coding and discussion, we ranked the drivers using a weighted system, where primary drivers were assigned 3 points, secondary 2 points, and tertiary 1 point. The results of this analysis form Appendix A. In cases where the rank of drivers was initially ambiguous, we revisited the data and further discussed and justified our individual coding to arrive at an agreed order. We captured websites at the time of interview, and website content and archival documents expanded our understanding of each hybrid's current legal structure, history, operations, goals, the issue they sought to address, and mission relating to that issue.

All but one hybrid was legally registered at the time data were collected (we retain the unregistered enterprise in the sample, because the entrepreneur was still able to provide insights about what was driving his decision process). Of our 48 case studies, 24 had changed their structure or were changing imminently. Figure 1 illustrates the changes occurring within and between for-profit, nonprofit, mixed-entity structures, ${ }^{16}$ and shows that mixed-entity structures are an increasingly popular choice among hybrids.

\section{What Drives the Initial Choice of Legal Structure?}

We found that social entrepreneurs choose their initial structure for a wide variety of strategic and personal reasons. There were 13 drivers of the initial choice of legal structure. Table 3 ranks these drivers and highlights whether they relate to organizational strategy, personal factors surrounding the founder, or both. The drivers are not mutually exclusive, and combinations of them often led founders to choose or alter their legal structure. Common combinations of drivers are highlighted in the descriptions below where applicable.

Up to this point, the assumption has been that social entrepreneurs choose their legal structure strategically to preserve tax benefits (for nonprofits) or social 
FIGURE I. Before and After View of Structural Change within Sample

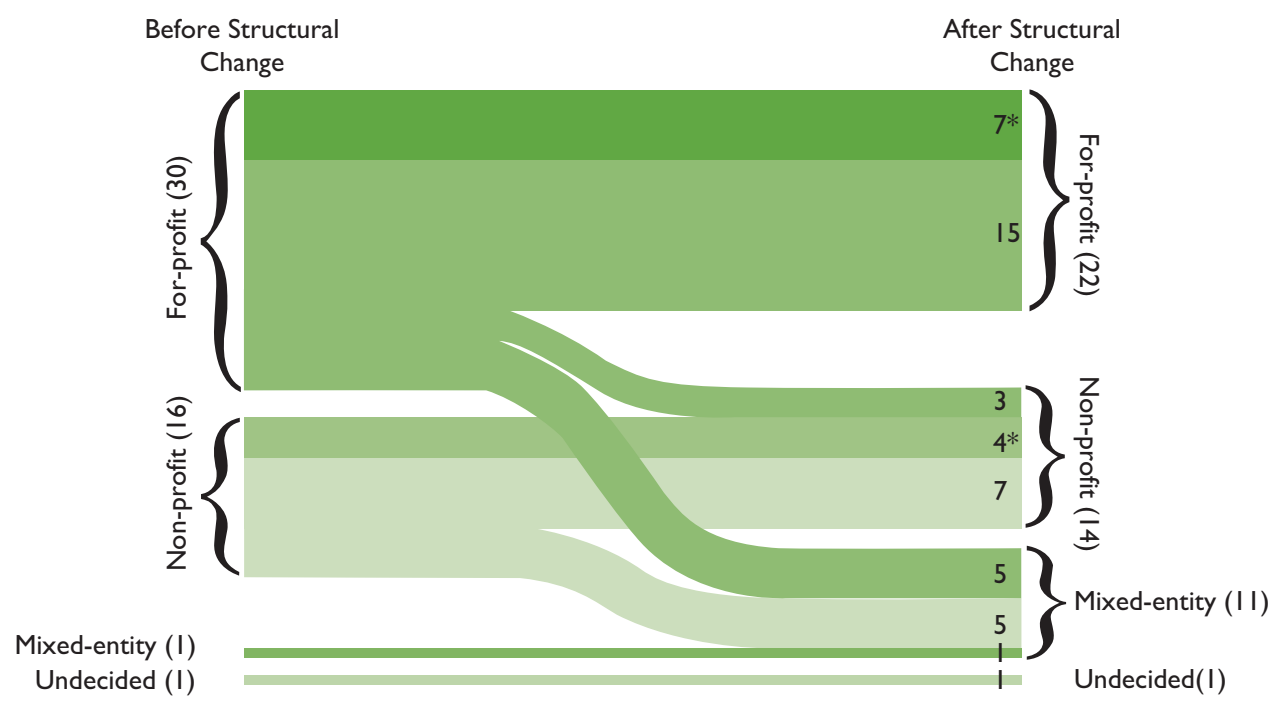

* Darker shaded areas within the for-profit and nonprofit categories indicate where hybrids changed legal structure but remained within their original structure type. Seven for-profits changed: Four switched to other for-profit structures, and three established second or third for-profit entities. Four non-profits changed: Two merged with larger non-profits, and two established second nonprofit entities.

impact, ${ }^{17}$ or gain access to capital and other resources. ${ }^{18}$ However, our findings show the picture to be significantly richer than first assumed. We found that the prevalence of personal and strategic drivers was balanced when making initial choices about legal structure. While strategic drivers like the need to raise capital and desire to facilitate the mission were most common, personal drivers like fit with founder values and identity and previous experience also played a large role in decision making about initial legal structure. In addition to this, as predictable as it might be that the need for capital ranked highly, it is perhaps equally unpredictable that other financial considerations_-such as tax and the generating revenue-ranked significantly lower than one might expect. In the following, we explain the top five drivers of initial legal structure choice listed in Table 3. These five drivers were significantly more common than were drivers ranking below them.

\section{Desire to Facilitate the Mission}

The most dominant driver shaping the structure of hybrid organizations we studied was the desire to find optimal ways to facilitate the mission. Social entrepreneurs believed that a particular structure was the best strategic vehicle for serving their mission. One social entrepreneur that chose to remain anonymous shared by e-mail that when initially starting their organization, "I insisted on our being a 
TAB LE 3. Drivers of Initial Legal Structure Choice

\begin{tabular}{|c|c|c|c|}
\hline Driver & Definition & $\begin{array}{l}\text { Strategic or } \\
\text { Personal? }\end{array}$ & $\begin{array}{l}\text { Weighted } \\
\text { Score }\end{array}$ \\
\hline $\begin{array}{l}\text { I. Desire to Facilitate } \\
\text { Mission }\end{array}$ & $\begin{array}{l}\text { The legal structure would best } \\
\text { support the mission of the } \\
\text { organization. }\end{array}$ & Strategic & 42 \\
\hline 2. Need to Raise Capital & $\begin{array}{l}\text { The legal structure would allow } \\
\text { initial capital to be raised most } \\
\text { effectively. }\end{array}$ & Strategic & 38 \\
\hline $\begin{array}{l}\text { 3. Fit with Founder } \\
\text { Values/Identity }\end{array}$ & $\begin{array}{l}\text { Social entrepreneur(s) had a specific } \\
\text { preference that aligned with their } \\
\text { values and/or identity. }\end{array}$ & Personal & 37 \\
\hline 4. Perceived Expedience & $\begin{array}{l}\text { Social entrepreneur(s) believed the } \\
\text { legal structure was less cumbersome } \\
\text { than others. }\end{array}$ & Strategic/Personal & 31 \\
\hline $\begin{array}{l}\text { 5. Previous Experience } \\
\text { of Founder }\end{array}$ & $\begin{array}{l}\text { Social entrepreneur(s) based the } \\
\text { choice on their previous } \\
\text { professional experience. }\end{array}$ & Personal & 27 \\
\hline $\begin{array}{l}\text { 6. Proving the Economic } \\
\text { Value of the } \\
\text { Intervention }\end{array}$ & $\begin{array}{l}\text { Social entrepreneur(s) wanted } \\
\text { to prove it was possible to } \\
\text { address their mission and } \\
\text { make money. }\end{array}$ & Personal & 13 \\
\hline 7. Fit with Product & $\begin{array}{l}\text { The legal structure was perceived to } \\
\text { be a good match for the good/ } \\
\text { service provided. }\end{array}$ & Strategic & 8 \\
\hline $\begin{array}{l}\text { 8. Never Considered an } \\
\text { Alternative }\end{array}$ & $\begin{array}{l}\text { Social entrepreneur(s) never } \\
\text { considered other legal registration } \\
\text { options. }\end{array}$ & Personal & 7 \\
\hline $\begin{array}{l}\text { 9. Need to be } \\
\text { Understood }\end{array}$ & $\begin{array}{l}\text { The legal structure would help } \\
\text { position the organization in a way } \\
\text { that stakeholders would deem } \\
\text { legitimate. }\end{array}$ & Strategic & 7 \\
\hline 10. Advice from Others & $\begin{array}{l}\text { Social entrepreneur(s) followed } \\
\text { advice offered by those close to } \\
\text { them. }\end{array}$ & Personal & 4 \\
\hline I I. Generate Revenue & $\begin{array}{l}\text { The legal structure allowed for } \\
\text { effective revenue generation. }\end{array}$ & Strategic & 2 \\
\hline 12. Need for Flexibility & $\begin{array}{l}\text { Social entrepreneur(s) selected a } \\
\text { legal structure they felt gave most } \\
\text { flexibility. }\end{array}$ & Strategic/Personal & 2 \\
\hline I3. Tax Considerations & $\begin{array}{l}\text { The legal structure offered specific } \\
\text { tax advantages. }\end{array}$ & Strategic & I \\
\hline
\end{tabular}

nonprofit because I was trying to change philanthropy. I wasn't trying to prove that you could make money and do good. Our goal is to change the way the world tackles poverty." In this case, the goal of changing how philanthropy tackles poverty dictated that nonprofit was the best choice. Souktel (described in Sidebar 1) was similarly mission-driven. Souktel started life as a for-profit because the founders saw it as the best vehicle to facilitate their mission of connecting job seekers with jobs. In an interview, co-founder Jake Korenblum indicated that this mission was a strong driver in all their start-up decisions: "we really started out by focusing on the core issue, which remains our core focus, which is the job information platform." 


\section{Need to Raise Capital}

Like most enterprises, securing capital was a crucial part of the start-up strategy for hybrids we examined. When one is prompted to think about raising capital, venture capitalists, debt financing, or (in the early stages) friends and family come to mind. Donations, grants, or other philanthropic funding are not traditionally thought of as capital. This driver predominantly resulted in social entrepreneurs choosing for-profit structures; however, several nonprofits we studied viewed grants and philanthropic funding sources as "socialized capital" that would help them fund early research and development or spread start-up risk. Embrace provides one example where founders initially chose a nonprofit structure to access philanthropic capital. Embrace is a 501 (c)(3) that developed a low-cost infant warmer designed for low-weight (and potentially hypothermic) babies in developing countries. Embrace donates the infant warmers, and provides education to health care workers and mothers about the care of low-weight babies. The infant warmer does not require electricity and costs a fraction of what traditional incubators cost to produce. One of the founders, Jane Chen, shared that she chose a nonprofit structure because:

“The idea was so early that it's hard to find venture capitalists with that level of risk appetite, especially given that the returns on this are just not going to look like a traditional medical device company. And so I think it would have been extremely difficult to raise that kind of money that early on."

The nonprofit structure allowed Embrace access to grants and donors that did not expect the economic returns that venture capitalists would have sought. Alternatively, one of the main reasons Gillian Henker founded her medical device company Sisu Global Health as a for-profit was to attract investors; though she registered it as an $\mathrm{L} 3 \mathrm{C}$ in the hope it would also allow the company to apply for grants. Sisu Global Health was created to address infant and maternal mortality in the developing world, and by working with physicians at the Komfo Anokye Teaching Hospital in Ghana has created products that include a blood transfusion device, a low-cost infant respirator, and a multi-functional labor and delivery bed. Enterprises whose legal structures were selected primarily to facilitate raising capital were some of the most likely to change legal structure in our sample.

\section{Fit with Founder Values or Identity}

The third important driver of initial choice of legal structure was a purely personal one-the perceived fit of a structure with founders' values or identity. Hybrids whose legal structure was selected based on fit with founders' values and identity were some of the least likely to change structure in our sample. Matthew Manos' company, verynice, is a good example of this. verynice is a for-profit design, innovation, and business consultancy based in Los Angeles that completes 50\% of its work pro-bono for nonprofits. After first considering starting a nonprofit, Manos founded verynice as a for-profit because remaining independent of donations and grants was important to him:

"My intention was to be $100 \%$ pro bono and to basically thrive off donations and support from grants and so on. But what I realized was that I really wanted to be 
self-sustaining and so I wanted to actually not have to rely on others to help me.... I became really fascinated by the concept of social enterprise... and that was a turning point where I realized...there are these models out there where you can still give back but you can be for-profit so that you can sustain yourself and just be independent. I really was attracted to the idea of being independent."

According to its website, verynice has donated over $\$ 1$ million in pro-bono design and consulting services to over 200 nonprofits, and is expanding its impact by making its business model available to others through a book called How to Give Half of Your Work Away for Free (available online or in print at givehalf.co).

\section{Perceived Expedience}

A number of social entrepreneurs founded for-profit hybrids because they wanted to move quickly toward their goals and avoid the red tape they perceived was associated with nonprofit models. These founders portrayed nonprofit models as bureaucratic and administratively cumbersome, so avoided them if they thought there was a chance of earning their own revenue. Social Conscience, a Canadian soccer ball company is one such example. James Milligan, the founder of Social Conscience, had studied sustainability and wanted to ensure his company would benefit communities in Pakistan where his soccer balls are made. He manufactures through the Fair Trade model, which adds a premium to the price of each ball to pay workers a living wage and establish worker representation to avoid worker exploitation. Milligan thinks of the arrangement as providing "funding for social programs from every ball," as the premiums have contributed to initiatives such as buying school supplies, providing fresh water to schools, and providing eye and diabetes examinations. Milligan concurred with other for-profits driven by perceived expedience when he said:

“I don't know what's involved with not-for-profit paperwork but I've got to believe it's more complicated than the for-profit paperwork...I didn't want to get too complicated about it...If I was to go back and look at it now anyway and start all over, I would still do it as for-profit...not to throw nonprofits under the bus when I say that; they obviously have a place in the market and a very necessary place."

Perceived expedience blends strategic and personal rationales because while social entrepreneurs sought to expedite their strategies, their perceptions are personal. Social entrepreneurs' perceptions of expedience were not usually grounded in experience, which sets this driver apart from the next driver (below) focusing on the previous experience of the founder (there was only one case where perceived expedience was cited as a primary decision driver alongside previous experience of the founder). In the above case, Milligan specifically indicated that he did not "know what was involved with not-for-profit paperwork." However, perceived expedience was frequently cited alongside the desire to facilitate the mission, suggesting that social entrepreneurs are not only seeking the best legal structure to facilitate their mission, but also one that will allow them to do it expeditiously.

\section{Previous Experience of the Founder}

The previous experience of founders was another driver factoring into the legal structure decision. This driver has a personal rationale, where some founders 
chose a structure because it concurred with their previous experience, while others went against their previous experience. On one hand, Alicia Vanderschuere wanted to leverage her experience in the retail world:

“It was always going to be for-profit with a social consciousness piece....My experience is in corporate America and I'm really great with product, that's what I enjoy and for me it was just a natural transition for me to come up with the for-profit side and to pursue that."

As a result, Vanderschuere's enterprise, RosieMADE, is a for-profit online store selling a variety of products made in the U.S. by women-owned businesses. Her aim is to increase the influence of women-owned businesses.

On the other hand, Rachel Zadeck had previously worked in nonprofits and was determined to avoid it when she established the Backpack Farm Agricultural Program (BPF). BPF provides a program of training and agricultural kits that help African families earn income, build skills, and feed themselves through conservation farming. Zadeck's goal is to improve food security among African nations; basing herself in Kenya. Zadeck had previously witnessed the limitations of food aid and stated, "I was planning to be a for-profit company. I had worked in the aid sector. I had worked in the U.N. I didn't want to be aid." She went on to describe why:

"I have done 13 years' work in post-conflict countries...I was one day standing on a runway in southern Sudan in the middle of nowhere and a lot of food drops... about 1,000 people over the next two hours sort of emerged out of the dust storm of the bush; and mostly women with children strapped to them and began to pick up 50-100 kilogram bags of maize meal or beans. And women were coming up to me and crying and trying to hand me their dead children and something in me broke... [I read] the research understanding the deficiencies of the food system, the expense of it...if we could give women bags of food that they may not even culturally want to eat and less than $2 \%$ of it meets nutritional requirements other than caloric intake, why could we not try to better package things that could help these women?"

\section{What Drives Legal Structure Change?}

Management scholars have rarely studied legal structure change; however, we found it was quite common in the hybrid organizations we studied-occurring in half the cases we examined, and in some cases multiple times. Dan Macombie of Runa was not alone in describing an evolution of legal structure that involved multiple stages. InVenture, a hybrid organization providing entrepreneurs in developing countries with financial skills and capital, is another example. CEO and Founder of InVenture, Shivani Siroya, told us that she first registered InVenture as a nonprofit in California, then registered a separate for-profit thinking the venture would be wholly for-profit, and ultimately settled on a mixed-entity hybrid that has both for-profit and nonprofit 501 (c)(3) entities. Siroya reported that after registering the for-profit, "We thought, 'Oh, we're not going to do anything with our nonprofit side,' and then realized that we actually had a need for it...We actually went back and forth and then finally landed on a [mixed-entity] hybrid model." 
Eleven drivers underpinned legal structure change, and these are ranked in Table 4. While the set of drivers is similar to that in Table 3, there are nuanced differences in what drivers represent at each decision point (we explain these below). In comparison to Table 3, which shows the top four drivers being most influential (as indicated by their weighted scores), Table 4 shows that changes to legal structure were predominantly influenced by the top two drivers. The other notable difference between the two tables is that while there was a balance between personal and strategic rationales driving initial legal structure choice, significantly more change drivers were strategic; likely the product of their being grounded in experience rather than perception. The top drivers of legal structure change are explained below.

\section{Desire to Better Facilitate the Mission}

The desire to better facilitate the mission was a prevalent driver among hybrids altering their structure. This driver was most common among for-profits that

TAB LE 4. Drivers of Legal Structure Changes (continued on next page)

\begin{tabular}{|c|c|c|c|}
\hline Driver & Definition & $\begin{array}{l}\text { Strategic or } \\
\text { Personal? }\end{array}$ & Weighted Score \\
\hline $\begin{array}{l}\text { I. Desire to Better } \\
\text { Facilitate Mission }\end{array}$ & $\begin{array}{l}\text { A change in legal structure } \\
\text { would better support the } \\
\text { mission of the organization. }\end{array}$ & Strategic & 44 \\
\hline $\begin{array}{l}\text { 2. Need to Raise } \\
\text { Capital }\end{array}$ & $\begin{array}{l}\text { A change in legal structure } \\
\text { would allow additional capital } \\
\text { to be raised more effectively. }\end{array}$ & Strategic & 19 \\
\hline $\begin{array}{l}\text { 3. Need to be } \\
\text { Understood }\end{array}$ & $\begin{array}{l}\text { A change in legal structure } \\
\text { would more clearly position } \\
\text { the organization in a way that } \\
\text { stakeholders would deem } \\
\text { legitimate. }\end{array}$ & Strategic & 13 \\
\hline $\begin{array}{l}\text { 4. Need to Diversify } \\
\text { Income }\end{array}$ & $\begin{array}{l}\text { A change in legal structure } \\
\text { would allow for the generation } \\
\text { of additional earned income. }\end{array}$ & Strategic & 8 \\
\hline $\begin{array}{l}\text { 5. Need for } \\
\text { Expedience }\end{array}$ & $\begin{array}{l}\text { A change in legal structure } \\
\text { would allow the organization } \\
\text { to operate more expediently. }\end{array}$ & Strategic & 5 \\
\hline $\begin{array}{l}\text { 6. Proving the } \\
\text { Economic Value of } \\
\text { the Intervention }\end{array}$ & $\begin{array}{l}\text { A change in legal structure } \\
\text { would enable social entrepreneur(s) } \\
\text { to prove it was possible to address } \\
\text { their mission and make money. }\end{array}$ & Personal & 4 \\
\hline $\begin{array}{l}\text { 7. Previous } \\
\text { Experience of } \\
\text { Founder }\end{array}$ & $\begin{array}{l}\text { Social entrepreneur(s) } \\
\text { changed legal structure to match } \\
\text { their previous professional } \\
\text { experience. }\end{array}$ & Personal & 3 \\
\hline $\begin{array}{l}\text { 8. Fit with Founder } \\
\text { Values or Identity }\end{array}$ & $\begin{array}{l}\text { Social entrepreneur(s) } \\
\text { changed the legal structure to align } \\
\text { more closely with their values and/ } \\
\text { or identity. }\end{array}$ & Personal & 2 \\
\hline
\end{tabular}


TABLE 4. Drivers of Legal Structure Changes (continued from previous page)

\begin{tabular}{|c|c|c|c|}
\hline Driver & Definition & $\begin{array}{l}\text { Strategic or } \\
\text { Personal? }\end{array}$ & Weighted Score \\
\hline 9. Need for Flexibility & $\begin{array}{l}\text { Social entrepreneur(s) switched } \\
\text { to a legal structure that gave the } \\
\text { most flexibility. }\end{array}$ & $\begin{array}{l}\text { Strategicl } \\
\text { Personal }\end{array}$ & 2 \\
\hline I0. Need for Control & $\begin{array}{l}\text { Social entrepreneur(s) switched } \\
\text { to a legal structure that afforded } \\
\text { them more control. }\end{array}$ & $\begin{array}{l}\text { Strategic/ } \\
\text { Personal }\end{array}$ & 2 \\
\hline $\begin{array}{l}\text { I I. Reduce Costs of } \\
\text { Doing Business }\end{array}$ & $\begin{array}{l}\text { A change in legal structure } \\
\text { offered an opportunity to reduce } \\
\text { business expenses. }\end{array}$ & Strategic & I \\
\hline
\end{tabular}

became mixed-entity hybrids where social entrepreneurs believed it would enable them to either enhance or stay true to their mission, or maintain control over their charitable contributions. For instance, RosieMADE was in the process of adding a nonprofit to the existing for-profit. Vanderschuere intends that " $2 \%$ of every sale will be diverted over to the foundation and then the foundation will have the ability...to help women with their endeavors" (women who are building their own craft businesses), and she wanted more control over how donations would be used and a closer relationship with beneficiaries:

"I considered the possibility of just doing charitable contributions but then I felt like the organization wouldn't necessarily have final say in how the money was being spent and I really liked the idea of being able to interact on a more personal level with the people who are seeking out funds."

\section{Need to Raise Capital}

The need to raise capital was the second most important driver of legal structure change. The trend towards hybridization was evident in this driver as it made strategic sense for enterprises such as InVenture, Sisu Global Health and Embrace to alter their structures to access new sources of capital. In an end-ofyear letter sent to Embrace supporters in 2012, the organization shared that it was adding a C-Corporation to its existing nonprofit:

"Our new structure will enable us to more rapidly access the capital needed to achieve our overall core objective: saving the lives of babies...By securing new sources of investment funding from private investors and socially minded venture capital firms, Embrace Innovations will be able to more quickly and effectively accomplish these activities, and bring our lifesaving healthcare technologies to those who most need them."

Under the new structure, the nonprofit Embrace owns the intellectual property for the low-cost infant warmer, while the for-profit Embrace Innovations is responsible for manufacturing, distributing and selling the infant warmer. This model gives Embrace scope to donate infant warmers to clinics in the most 
poverty-stricken areas while earning license fees from sales made by Embrace Innovations.

\section{Need to be Understood}

It was important to the social entrepreneurs we interviewed that their hybrids appear legitimate in the eyes of investors, regulators, and customers. This driver was strategic and was cited alongside either "desire to better facilitate the mission" or "need to raise capital" drivers. It predominantly resulted in switches to or within the for-profit category. We use the term "need to be understood" to label this driver, because the word "understood" was used by interviewees when describing what drove them to change structures. For instance, one interviewee who chose to remain anonymous mentioned their hybrid switched from nonprofit to mixed-entity, because:

"It allowed us to bring in outside investors and it was something that the outside investment world understood and was comfortable with... It meant that in the eyes of the federal government we were easily understood."

Similarly, after initially establishing an L3C, Sisu Global Health changed to C-Corporation to raise capital after realizing that it was not "getting as much out of the L3C as we initially anticipated" in terms of grant funding because neither foundations or investors understood the L3C structure yet, while C-Corporations were better understood by traditional investors.

The need to be understood also appeared as a lower-ranking driver of initial structural choice, where it differed in that it chiefly drove social entrepreneurs to establish nonprofits so their enterprise would be understood by partners, donors, the public, and beneficiaries. Dan Macombie's earlier statement that Runa's original nonprofit was started to host the supply chain in the belief that this "was necessary for communicating our social mission to farmers" exemplifies this. In aggregate, the changing nature of this driver between initial choice and structural change decisions reflects the different mixes of stakeholders from whom social entrepreneurs were seeking legitimacy, and underscores the shift in the driver becoming more strategic in nature.

\section{Need to Diversify Income}

The need to diversify income predominantly arose as nonprofit hybrids focused on strategies to earn more revenue. This driver is distinct from the need to raise capital, in which hybrids focused on accessing pools of investment or philanthropic money. This driver typically resulted in nonprofits becoming mixedentity hybrids as they developed new goods and services or accessed new markets through the for-profit entity. MTI IBD had already added a number of services to its portfolio with the explicit aim to "employ more [veterans] and bring in greater revenues," and intended that a for-profit would enable them to access mainstream markets. CEO Wendell Knight explained that:

"Presently we have the driving range...two cafes plus catering that we do...We are adding a putting green plus a mini golf course to it, which will employ more 
veterans and plus the greenhouse...Also wanting to be able to put in our gourmet vegetables and herbs so we can cater more to the restaurants... We get a lot of catering now and that will be enhanced and we will be more competitive."

MTI IBD's drive to expand its market to increase revenue through a forprofit entity was not unusual among nonprofits as they designed for-profit businesses to support the nonprofit.

\section{Need for Expedience}

Expedience was a mid-ranking driver of both initial choice of structure and structural change. As a driver of initial choice structural choice, expedience surrounded perceived inefficiencies embedded within nonprofit structures. However, as a driver of structural change it was somewhat different. The first difference is that this driver was based on experience rather than perceptions, as entrepreneurs had learned what structural options were optimal for achieving their goals, and why their current structure was not. The change in the nature of this driver moves it closer to the initial choice driver "previous experience of founder;" however, we have not renamed it because as Table 4 shows, "previous experience of founder" also drove structural change and changed in nature as social entrepreneurs switched legal structures to fit their previous experience.

The second difference is that the driver became strategic in nature rather than encapsulating a mixed personal-strategic rationale. One anonymous social entrepreneur initially registered their hybrid as a for-profit in the U.S. though it conducted all business in Mali. They realized it would be more expedient to re-register in Mali because foreign companies had fewer legal protections and were taxed at a higher rate. This hybrid was one that changed structure but remained in the for-profit category-shifting from a U.S.-based LLC to become a Mali-based LLC.

The third difference is that entrepreneurs switched to or established nonprofits because they found them more expedient. In some instances, founders had switched to or added a nonprofit because it proved more expedient after initially choosing for-profit because it was perceived more expedient. One such hybrid was benevola-Ben Aymé founded benevola as a for-profit company that matches people to volunteering opportunities based on their professional skills and talents. One reason Aymé initially established a for-profit was that it was perceived as the more expedient option for his goals. At the time of interview, however, he was planning the addition of a nonprofit to address technical difficulties he experienced being a pass-through for charities that benevola supported in addition to the skills-matching service:

"When we started we did set up donations to the causes that we work for... So as a novice we do that direct, but the next phase is to set up a foundation for that, to have a special vehicle for that...I could not find a global partner so I thought, 'It's probably easier to set up our own foundation, which will have much more flexibility and not be restrained to lose a few percent here and there."' 


\section{Concluding Insights and Recommendations}

Over the course of this inquiry into what drives initial and subsequent choices of legal structure among hybrid organizations, three core insights emerged that offer practical advice for social entrepreneurs and businesses looking to collaborate with hybrid organizations or wanting to go beyond the scope of current CSR initiatives. The first insight surrounds the need for hybrids to remain flexible so they can continue to serve their mission while remaining economically viable. Our second insight surrounds the decision-making of hybrids becoming strategic over time as the legal structure becomes the vehicle through which social entrepreneurs balance economic and social goals. Our third insight points to ways that traditional firms can utilize structural flexibility themselves to push CSR and corporate sustainability efforts forward.

\section{Hybrids Desire Flexibility}

If one word could encapsulate what social entrepreneurs seek by the changes they make to their enterprises it is flexibility. The hybrid organization landscape is quickly evolving as options in legal structure grow, and social entrepreneurs are choosing and changing legal structures to give their enterprise more flexibility in how they deliver on their mission and remain financially viable. The need for flexibility was mentioned specifically in only a few cases (ranking $12^{\text {th }}$ in Table 3 and $9^{\text {th }}$ in Table 4); however, a holistic view of our results indicates thatwhen needed-social entrepreneurs will alter their legal structure to gain any flexibility they need. Social entrepreneurs use this flexibility for two main purposes, which are reflected in the two highest-ranking drivers affecting initial structure decisions and decisions to change structure. First, social entrepreneurs are choosing and switching legal structures to further their mission so they have the option to better control their philanthropic efforts (e.g., RosieMADE), work with particular types of partners (e.g., Souktel), or to start work that lies outside the confines of existing grant, philanthropic or partnership arrangements (e.g., MTI IBD). The second use of flexibility by hybrids is to increase their options for raising investment and philanthropic capital, as was the case with Embrace and Sisu Global Health. In relation to raising capital, structural flexibility was also useful in helping entrepreneurs to overcome their initial misjudging of funding sources. Sisu Global Health initially established an L3C to appeal to both investors and philanthropists, but after experiencing a lack of understanding about the L3C form among both groups, it switched to C-Corporation to appeal to traditional medical device investors.

Social entrepreneurs and their partners should carefully consider the need for and implications of structural flexibility. In the beginning of this article, we suggested that switching structures might alter the value proposition of partnerships. Figure 1 showed that the need for flexibility is leading to mixed-entity hybrids becoming common. The mixed-entity structure enables great flexibility, since it facilitates various configurations of ownership, management of assets and intellectual property, transfer of economic value, risk allocation, and governance. However, delineating access and fair compensation between the entities 
can be complex since it is often facilitated by contracts. Sidebar 3 explains the configurations among mixed-entity structures as they appeared in our sample.

\section{Sidebar 3. The Inner Workings of Mixed-Entity Hybrid Organizations}

For-Profit Donates Cash to Nonprofit-One popular configuration is for the for-profit to support the nonprofit by donating to it some or all of the profit. One enterprise we studied working towards this was Pink Wish Foundation, a U.S. nonprofit working to stop self-destructive behavior and economic distress among girls aged 8-18. At the time of interview, Pink Wish Foundation was in the midst of establishing a for-profit to sell cosmetics that would "make the contributions that we have vowed to make to keep going." MTI IBD and RosieMADE are other examples. In some cases, such as MTI IBD, the for-profit may also provide work for beneficiaries. This configuration was popular among hybrids wanting to provide the nonprofit with a steady stream of revenue, and those that wanted to retain more control over how donations were used. Though it was not a strong driver among our data, a further benefit surrounds the for-profit and external donors receiving tax benefits for their donations. This configuration shares some similarity (though not typically in size or level of mutual engagement in operations) with corporations that create a separate entity to manage some or all of their philanthropic activities, as is the case with Dow Chemical Company and The Dow Chemical Company Foundation.

\section{Nonprofit Distributes For-Profit's Products to Humanitarian}

Markets-Another popular configuration emerged where nonprofits would facilitate the distribution of the for-profit's products to humanitarian markets for free or at subsidized rates. This was the case with Souktel, which became a mixed-entity so it could collaborate with aid organizations and implement its text-based technology for humanitarian purposes more effectively. This structure can enhance the ability of a hybrid to establish partnerships with NGOs and governmental aid agencies that already have expertise, credibility, and established distribution channels in a given market. This configuration can also increase the scale of production for the for-profit (which may be selling the same products at a premium in different markets), and such relationships can be implemented using typical product pricing and distribution agreements.

Nonprofit Owns Shares in the For-Profit-In this configuration, the nonprofit retains a shareholding in the for-profit. In our sample, this configuration provided the nonprofit with dividend income; however, other reasons for adopting it include ensuring the nonprofit has a role in governing the for-profit (if the shareholding is large) and tax benefits the for-profit will receive for any donations. An example of this configuration from our 
sample comes from Ubuntu Bikes, a hybrid based in South Africa that builds and restores unique bicycles. The for-profit Ubuntu Bikes hires local vendors (often charities) to provide bicycles, artwork, and accessories. The nonprofit side (Ubuntu Trust) has a 20\% shareholding in Ubuntu Bikes and uses the income to support local charities.

Nonprofit Owns Intellectual Property Licensed by the For-

Profit-Hybrids developing intellectual property have the option of situating intellectual property associated with the mission in the nonprofit. Embrace established this configuration to develop its medical device using grant and philanthropic funding prior to establishing the for-profit Embrace Innovations to manufacture and sell the device. Other reasons for establishing this configuration might include providing the nonprofit with income via license fees from sales by the for-profit. In these cases, the nonprofit may also have a shareholding in the for-profit to provide structure for governance oversight to ensure fair compensation to the nonprofit for its development of assets.

The descriptions in Sidebar 3 show how the drivers of structural change can influence the relationship between nonprofit and for-profit entities, and subsequently which entity will manage various assets, risks, costs, and operations. The result may enhance or detract from the value of a partnership, or even negate the hybrid's need for a partnership. Basic considerations are which entities will be party to the partnership, and what aspects of the enterprise will reside within which entity. Addressing these considerations prior to partnering with a mixedentity hybrid will help to avoid perceived or real misallocation of costs and benefits, which is a common issue among social alliances. ${ }^{19}$

More generally, companies should research potential hybrid partners thoroughly to determine whether they are likely to change their legal structure, and what impact a change might have on the ability of the partnership to deliver its intended outcomes. Our results suggest that knowing whether the initial structure was chosen for personal reasons (such as fit with founders' values) as opposed to strategic reasons (like the need to raise capital) can inform companies of the likelihood of future change in the hybrid. Though the incidence of change in our entire sample was 50\%, those legal structures initially driven by predominantly personal reasons appeared slightly more resistant to legal structure change (e.g., $45 \%$ of structures driven by fit with founders' values changed), while those initially driven by strategic reasons were more likely to change (e.g., $75 \%$ of structures chosen to fit with a product, and $65 \%$ of structures chosen to raise capital). Any company considering entering a partnership with a hybrid organization should have explicit conversations with its leadership to understand what is driving their structural choices and their commitment to the current structure.

Similarly, social entrepreneurs designing or redesigning their enterprise should consider potential benefits and risks that a given structure and alterations to it may carry for its partners and partnerships. In particular, thought should be given to how legal structure change may affect identified building blocks of partnerships. ${ }^{20}$ 
For instance, would a change to the hybrid's legal structure affect the ability of parties to build collective strength? Would a change to the hybrid's legal structure affect the legitimacy of parties or the partnership in the eyes of important stakeholders? Would a change to the hybrid's legal structure affect the desired level of interdependence between parties? Would a change to the hybrid's legal structure create conflict?

\section{Hybrids Become More Strategic over Time}

The second insight is evident when comparing Table 3 and Table 4, which is that, in aggregate, decisions surrounding legal structure become increasingly strategic over time. In our sample, a balance of personal and strategic drivers drove initial structural choices, while changes to legal structure were more likely to be strategic. We also observed the expedience-related driver becoming strategic in orientation between the two decision points. This reflects experience gained by social entrepreneurs about how their enterprise can work within the landscape of stakeholders, available structures, and mixed-entity hybrid configurations to deliver on their mission and remain economically viable. One lesson learned by many social entrepreneurs surrounded the need for-and opportunities available through-partnerships. Changes to structure were often undertaken to enter a partnership or in anticipation of partnerships-Souktel's establishment of a nonprofit to develop software with NGOs is a clear example of this. The key insight here is that should a corporate partner be of sufficient potential benefit, hybrid organizations should be willing to adapt their structure, and companies should not overlook a potential partner because its current legal structure is not appealing.

Our results also suggest that social entrepreneurs are learning how to strike a balance between social and economic goals. Previous studies have focused on the challenges $^{21}$ of managing humanitarian and market objectives ${ }^{22}$ and have found that hybrids demonstrate dual identities to manage tensions between the two. ${ }^{23}$ Given the two most prevalent drivers across both decision points surrounded facilitating the mission and raising capital, we expected to find the same tensions expressed in our cases; however, we found a noteworthy absence of such tensions in the 48 hybrids we studied. This leads us to conclude that while scholars focus on such tensions, social entrepreneurs focus on solutions to them, and changes to legal structure may be one manifestation of such solutions.

\section{Traditional Companies Can Hybridize}

Our third insight is an implication of our results; namely, that a focus on flexibility need not only be the preserve of social entrepreneurs, because traditional companies can also use a flexible approach to their own legal structure to push their CSR or corporate sustainability initiatives forward. Structuring a company to diversify and solidify its access to markets, revenue, and financing is a familiar practice of corporate directors, while engaging with social and environmental issues already lies squarely within the scope of work performed by CSR and sustainability managers. Further, some corporations already have a long history of creating separate nonprofit entities to manage their philanthropy, as we mentioned in Sidebar 3. Based on these existing skills and experience, hybridizing a traditional 
for-profit firm may be viable where leaders want to move beyond (or add to) partnerships with nonprofits and deepen their engagement with social and environmental issues affecting their stakeholders, or to gain more flexibility or control in the implementation of existing CSR initiatives.

A for-profit executive might think that establishing a nonprofit organization would be an obvious choice for a hybridizing a for-profit business, and if that is the case, the information in Sidebar 3 can assist in designing the relationship between the firm and a new nonprofit entity. Leaders considering the addition of a nonprofit must ensure they are aware of the essential aspects of nonprofit management, since nonprofit structures are more restrictive and more regulated than for-profit structures. A thorough analysis and implementation plan specifying the separation of assets, costs, resources, and activities is critical.

However, several of our cases had established additional entities of the same type as the original entity (see the shaded areas of Figure 1), and there are wellknown examples (but not in our sample) where corporations have added mission-driven for-profits to their portfolio. One example is Google's philanthropic organization http://Google.org, which was established as a for-profit to provide flexibility for undertaking such initiatives as funding start-ups. ${ }^{24}$ Another example is Groupe Danone's merger with Stonyfield Farm. The Groupe Danone/Stonyfield Farm merger exemplifies a degree of hybridization by merger, and it suggests ways that firms can hybridize and pursue their normal range of corporate goals-such as entering new markets, developing new products, and maximizing innovation and market share. Groupe Danone targeted Stonyfield Farm because it was grappling with its environmental management priorities and wanted to reduce carbon emissions, and Stonyfield Farm's Founder and CEO Gary Hirshberg was on the cutting edge of thought leadership in the U.S. dairy industry. ${ }^{25}$ Stonyfield Farm began in 1983 as a nonprofit organic farming school aiming to "help family farms survive, keep food and food production healthy, and help protect the environment." ${ }^{26}$ Stonyfield Farm produced organic yoghurt to fund the school, before becoming a for-profit company producing organic dairy products. In 2001, Groupe Danone began a progressive merger that would see it acquire $80 \%$ of Stonyfield Farm by 2003. ${ }^{27}$ Members of the social enterprise community were initially critical of the merger, citing fears that Stonyfield Farm's "commitment to sustainability would likely be toned down;" however, it has benefited both companies. Since the merger, Groupe Danone has expanded its commitment to sustainable food chain management, developed plant-based packaging, acquired further organic dairy companies, and launched Stonyfield Europe to provide organic alternatives to Groupe Danone's other European brands. ${ }^{28}$ While we leave it to future research to examine such transitions, our findings about what drives entrepreneurs to choose one structure over another may help any leaders considering hybridization make the choice between for-profit and nonprofit for a new entity.

Hybrid organizations are adapting their legal structure to optimize their ability to succeed in complex and dynamic environments. Social entrepreneurs do not view legal structure as fixed, but rather as a variable aspect of their enterprise that can shift to better facilitate the mission, raise capital, gain legitimacy, diversify income, or expedite any or all of these. Entrepreneurs and managers of non-hybrid 
firms can leverage hybrid structures to advance their current CSR program or address other strategic issues.

APPENDIX A

\begin{tabular}{|c|c|c|c|c|c|}
\hline $\begin{array}{l}\text { Initial Choice } \\
\text { Driver Ranking }\end{array}$ & $\begin{array}{c}\text { Number of } \\
\text { Primary } \\
\text { Drivers }\end{array}$ & $\begin{array}{c}\text { Number of } \\
\text { Secondary } \\
\text { Drivers }\end{array}$ & $\begin{array}{c}\text { Number of } \\
\text { Tertiary } \\
\text { Drivers }\end{array}$ & Total & $\begin{array}{l}\text { Weighted } \\
\text { Score }\end{array}$ \\
\hline $\begin{array}{l}\text { Desire to Facilitate the } \\
\text { Mission }\end{array}$ & 8 & 9 & & 17 & 42 \\
\hline Need to Raise Capital & 7 & 7 & 3 & 17 & 38 \\
\hline $\begin{array}{l}\text { Fit with Founder Values } \\
\text { or Identity }\end{array}$ & 9 & 5 & & 14 & 37 \\
\hline Perceived Expedience & 8 & 3 & । & 12 & 31 \\
\hline $\begin{array}{l}\text { Previous Experience of } \\
\text { Founder }\end{array}$ & 7 & 2 & 2 & 11 & 27 \\
\hline $\begin{array}{l}\text { Proving the Economic } \\
\text { Value of the } \\
\text { Intervention }\end{array}$ & 3 & 2 & & 5 & 13 \\
\hline Fit with Product & 2 & । & & 3 & 8 \\
\hline $\begin{array}{l}\text { Never Considered an } \\
\text { Alternative }\end{array}$ & 2 & & I & 3 & 7 \\
\hline Need to be Understood & I & 2 & & 3 & 7 \\
\hline Advice from Others & & 2 & & 2 & 4 \\
\hline Generate Revenue & & l & & । & 2 \\
\hline Need for Flexibility & & I & & I & 2 \\
\hline Tax Considerations & & & I & I & I \\
\hline
\end{tabular}

\begin{tabular}{lcccc}
\hline Change Driver & $\begin{array}{c}\text { Number of } \\
\text { Primary } \\
\text { Ranking }\end{array}$ & $\begin{array}{c}\text { Number of } \\
\text { Secondary } \\
\text { Drivers }\end{array}$ & $\begin{array}{c}\text { Number of } \\
\text { Tertiary } \\
\text { Drivers }\end{array}$ & $\begin{array}{c}\text { Total } \\
\text { Score }\end{array}$ \\
\hline
\end{tabular}

Desire to Better

$\begin{array}{rrrrr}11 & 5 & 1 & 17 & 44 \\ 5 & 2 & & 7 & 19 \\ 3 & 2 & 5 & 13 \\ 1 & 2 & 1 & 4 & 8 \\ 1 & 1 & & & \\ 1 & & 1 & 2 & 4\end{array}$

Need to Raise Capital

Need to be Understood

Need to Diversify

Income

Need for Expedience

Proving the Economic

Value of the

Intervention

Previous Experience of

Founder

Fit with Founder Values

or Identity

Need for Flexibility

Need for Control

Reduce Costs of Doing

Business 


\section{Notes}

1. N. Haigh and A.J. Hoffman, "Hybrid Organizations: The Next Chapter of Sustainable Business," Organizational Dynamics, 41/2 (2012): 126-134.

2. D. Smallbone, M. Evans, I. Ekanem, and S. Butters, "Researching Social Enterprise," Final Report to the Small Business Service, Centre for Enterprise and Economic Development Research, Middlesex University Business School, London, 2001; J. Battilana and S. Dorado, "Building Sustainable Hybrid Organizations: The Case of Commercial Microfinance Organizations," Academy of Management Journal, 53/6 (December 2010): 1419-1440.

3. B. Boyd et al., Hybrid Organizations: New Business Models for Environmental Leadership (Sheffield, UK: Greenleaf Publishing, 2009).

4. K. Alter, Social Enterprise Typology (Seattle, WA: Virtue Ventures LLC, 2007).

5. J. Battilana, M. Lee, J. Walker, and C. Dorsey, "In Search of the Hybrid Ideal," Stanford Social Innovation Review, 10/3 (Summer 2012): 51-55.

6. S. Bacq and F. Janssen, "The Multiple Faces of Social Entrepreneurship: A Review of Definitional Issues Based on Geographical and Thematic Criteria," Entrepreneurship $\theta$ Regional Development, 23/5-6 (June 2011): 373-403.

7. L3Cs and their equivalents are technically "low profit" for-profit and have a strong social mission and constraints around asset and profit management, but may identify either as a nonprofit or for-profit. For the purpose of this study, we have included them in the for-profit category.

8. J. Kickul and T.S. Lyons, Understanding Social Entrepreneurship: The Relentless Pursuit of Mission in an Ever Changing World (New York, NY: Routledge, 2012).

9. I.E. Berger, P.H. Cunningham, and M.E. Drumwright, "Social Alliances: Company/Nonprofit Collaboration," California Management Review, 47/1 (Fall 2004): 58-90; G. Liu and W.W. Ko, "An Analysis of Cause-Related Marketing Implementation Strategies Through Social Alliance: Partnership Conditions and Strategic Objectives," Journal of Business Ethics, 100/2 (May 2011): 253-281; G. Walters and C. Anagnostopoulos, "Implementing Corporate Social Responsibility through Social Partnerships," Business Ethics: A European Review, 21/4 (October 2012): 417-433.

10. M. Di Domenico, P. Tracey, and H. Haugh, "The Dialectic of Social Exchange: Theorizing Corporate-Social Enterprise Collaboration," Organization Studies, 30/8 (2009): 887-907.

11. Liu and Ko, op. cit.

12. M. Alvesson, “Beyond Neopositivists, Romantics, and Localists: A Reflexive Approach to Interviews in Organizational Research," Academy of Management Review, 28/1 (January 2003): 13-33; K.M. Eisenhardt, "Building Theories from Case Study Research," Academy of Management Review, 14/4 (October 1989): 532-550.

13. C. Noy, "Sampling Knowledge: The Hermeneutics of Snowball Sampling in Qualitative Research," International Journal of Social Research Methodology, $11 / 4$ (October 2008): 327-344.

14. K. Browne, "Snowball Sampling: Using Social Networks to Research Non-Heterosexual Women," International Journal of Social Research Methodology, 8/1 (February 2005): 47-60.

15. Eisenhardt, op. cit.

16. Enterprises undergoing structural change were almost as globally dispersed as the entire sample, and had similarly been in operation for between 1-42 years; though 55\% were 5 years or under.

17. Battilana, op. cit.

18. D.M. Townsend and T.A. Hart, "Perceived Institutional Ambiguity and the Choice of Organizational Form in Social Entrepreneurial Ventures," Entrepreneurship: Theory $\theta$ Practice, 32/4 (July 2008): 685-700.

19. Berger et al., op. cit.

20. Liu and Ko, op. cit.

21. S. Dolnicar, H. Irvine, and K. Lazarevski, “Mission or Money? Competitive Challenges Facing Public Sector Nonprofit Organisations in an Institutionalised Environment," International Journal of Nonprofit $\theta$ Voluntary Sector Marketing, 13/2 (May 2008): 107-1 17.

22. J. Jay, "Navigating Paradox as a Mechanism of Change and Innovation in Hybrid Organizations," Academy of Management Journal, 56/1 (February 2013): 137-159.

23. T.W. Moss, J.C. Short, G.T. Payne, G. Tyge, and G.T. Lumpkin, "Dual Identities in Social Ventures: An Exploratory Study," Entrepreneurship: Theory o Practice, 35/4 (July 2011): 805-830.

24. K. Hafner, "Philanthropy Google's Way: Not the Usual," The New York Times, September 14, 2006.

25. N.F. Koehn, N.N. Khan, and E.W. Legris, "Gary Hirshberg and Stonyfield Farm," Harvard Business School Case 312-122, March 2012. 
26. Amy Van Haren, "At Stonyfield, the Healthy Mission Came First, Yogurt Making Second," <www.stonyfield.com/blog/about-stonyfield/\#sthash.gCPTJFXW.dpuf>, accessed December $1,2014$.

27. Koehn et al., op. cit.

28. Koehn et al., op. cit. reproduce article content at the University of California Press's Rights and Permissions website at http://www.ucpressjournals.com/reprintinfo.asp. DOI: 10.1525/cmr.2015.57.3.59. 